\title{
ALGUNAS INDICACIONES BIBLIOGRAFICAS SOBRE LA EUROPA DEL SUR EN LOS SIGLOS XIX Y XX: GRECIA Y TURQUIA ${ }^{1}$
}

\author{
ELOY FERNANDEZ CLEMENTE \\ Universidad de Zaragoza
}

\section{INTRODUCCION}

La aparición de algunas informaciones bibliográficas ${ }^{2}$ y de diversas noticias sobre estudios relativos a la Europa del Sur me animan a ofrecer una primera aproximación a algunos repertorios bibliográficos sobre los casos de Grecia y Turquia y su evolución económica entre, aproximadamente, mediados del XIX (la independencia griega anterior, el largo devenir del imperio otomano) y mediados del XX (el final de la dictadura de Metaxás, la muerte de Ataturk, en definitiva, los aledaños de la II Guerra Mundial). En cuanto a Portugal, remitiré al lector interesado a un reciente trabajo mío ${ }^{3}$.

1 Debo agradecer aquí las muchas ayudas, materiales $e$ intelectuales, recibidas, de una parte, de mi Universidad de Zaragoza, asi como de las de Atenas, Estambul, Cambridge, Comell, la Fundación Gennadius de Atenas y el Instituto Europeo de Florencia, en cuyas bibliotecas he encontrado siempre todo tipo de facilidades y fondos con frecuencia magníficos. Ayudas igualmente del Consejo Asesor de Investigación en Aragón y la Caja de la Inmaculada. Y asesoramiento de personas cuya cita seria interminable, pero que deben figurar, al menos, los profesores G. Dertilis, N. Diamandouros, K. Kostas y otros varios en Grecia, y Çaglar Keyder, en Estambul y Binghamton. El trabajo emprendido para estudiar una parte de la Historia Económica de estos paises me ha llevado varios años $\mathrm{y}$, dada su ambición y mis limitaciones, habrá de esperar aún algún tiempo a materializarse. De ahí que, aprovechando algunas buscas marginales, crea de alguna utilidad ofrecer a un gran público lector especializado en temas económicos y políticos estas notas bibliográficas.

2 Especialmente me refiero al art. de Clara Eugenia Núñez y Antonio Tena (1985) «Problemas históricos del desarrollo y atraso económico en la Europa del Sur: Italia, España y Portugal, 1830-1930x, Pensamiento Iberoamericano, n. ${ }^{\circ} 7$, pp. 293-302 y 293-302.

3 E. Fernández Clemente, "La historia económica de Portugal, siglos XIX y XX», Revista de Historia Económica, VI, 3, 1988, pp. 481-520. 


\section{A) GRECIA, DESDE LA INDEPENDENCIA HASTA LA II GUERRA MUNDIAL}

\section{Estudios generales}

Entre las no muy abundantes pero suficientes historias generales, asequibles en idiomas inglés o francés, destacariamos la reedición de la escrita hace medio siglo por Edward S. Forster $A$ Short History of Modern Greece, 18211956, Londres, 1958; la muy clásica de Nicolás Svoronos, Histoire de la Grèce moderne, Paris, 1953; la ya prestigiosa de Richard Clogg $A$ short History of Modern Greece, Cambridge University Press, 1966; la también inglesa y prestigiada de J. Campbell y Ph. Sherrard Modern Greece. Londres, 1968; su coetánea de C. M. Woodhouse Modern Greece. A short History, Londres (4." ed. en 1986, la 1.a de 1968), y la excelente obra colectiva editada por Marion Sarafis y Eve Martin, Background to contemporary Greece, Londres, 1990, en dos volúmenes, en que destacaríamos el documentado trabajo de John Kofas "The Greek economy" (pp. 53-93 del vol. I). En cuanto a los interesados en una sintesis en español, por fin disponemos de una discreta, la de $T$. Boatswain y C. Nicolson Una viaje por la Historia de Grecia, Celeste ediciones, Madrid, 1991, inspirada en el gran interés de los turistas españoles por el vecino país mediterráneo, y que dedica un centenar de páginas a los siglos XIX y XX.

\section{E1 largo plazo en la economía}

Una serie de interesantes congresos o trabajos colectivos han repasado recientemente cuestiones económicas a largo plazo. Así, en el II Coloquio Internacional celebrado en Atenas, se estudiaron las Economies Méditerranéennes: Equilibres et Intercommunications, XIle-XIXe siècles (Atenas, 1985). Destacan trabajos como los de Dertilis, «Hiérarchies sociales, capitaux et retard économique en Grèce (XVIIIe-XXe siècle)»; V. Protzas, "Produit agricole et cadre technologique en Thessalie au début du XXe. siècle»; M. Riginos, Michalis, «Prix, salaires journaliers et pouvoir dachat en Grèce (1909- 1936)»; C. Agriantoni, Christine, «L'industrie Grecque au XIXe siècle. Périodisation. Problèmes d'intégration».

Por su parte, la francesa Fundación de Treilles celebró un seminario, dirigido por G. B. Dertilis, sobre Banquiers, usuriers et paysans. (Réseaux de crédit et stratégies du capital en Grèce (1780-1930).) (Fondation des Treilles/ Ed. 
La Découverte. París, 1988). Alli se publican trabajos como el del propio Dertilis, «From tithe to income tax, Greece 1830-1985».

Un trabajo de especial interés por su ámbito general balcánico y el largo periodo de estudio es el de J. R. Lampe y M. R. Jackson, Balkan Economic History, 1550-1950. From Imperial Borderlands to Developing Nations. Bloomington. Indiana University Press, 1982.

Nicos P. Mouzelis es un autor muy estimado en el mundo anglosajón por trabajos como Modern Greece. Facets of Underdevelopment (Londres, 1979), su artículo «Capitalism and the Development of the Greek State», publicado en R. Scase (ed.): The State in Western Europe, Londres, 1980, pp. 241-249, y un nuevo libro: Politics in the Semi-Periphery. Early Parliamentarism and late industrialisation in the Balkans and Latin-America. Hong-Kong. MacMillan, 1986.

En torno a 1971 aparece el breve pero enjundioso estudio de $\mathbf{M}$. Negreponti-Delivanis Greece in transition 1821-1971. Economic Aspects.

\section{Algunas monografias}

En cuanto a estudios sobre aspectos especificos, una visión panorámica sobre la demografia, en Vasilios G. Valaoras, «A reconstruction of the demographic History of Modern Greece", en The Milbank Memorial Fund Quarterly, 1960, XXXVIII, 2, pp. 115-139.

La agricultura, desde el punto de vista de los cambios en la propiedad de la tierra, es estudiada por William W. McGrew, Land and Revolution in Modern Greece, 1800-1881, Kent State University Press, 1985. Y sobre los cambios en los cultivos hay que destacar a Evangélos Prontzas, La monetarisation et la différenciation des cultures en Thessalie (1881-1912) (tesis doctoral presentada en 1986 en la Universidad de Paris-I: Panthéon-Sorbonne, inédita). Ya para el siglo XX, en un período de especial importancia, Kostas Kostis es autor de una importante tesis doctoral, aún inédita, que sepamos, sobre Economie agricole et Banque agraire. Aspects de leconomie de la Grèce entre les deux guerres (1919- 1928). París, 1985, EHESS.

Los orígenes de la industrialización, en Vasilis Panayotopoulos, «La revolution industrielle et la Grèce, 1832-1871", en Etudes Balkaniques, 3, 1977, pp. 92-98. Sofia.

Un trabajo que contempla en largo plazo el sistema bancario es el de Andreas Kyrkilitsis «The Greek banking system: A historical review», Revwe Internationel d'Histoire de la Banque, 1, pp. 126 ss. Ginebra, 1968. 


\section{Las etapas}

En cuanto a los principales periodos de la economía griega del siglo $\mathrm{XX}$, podemos citar, sobre el gran tema de los enormes cambios demográficos del período entreguerras, el estudio de Dimitri Pentzopoulos The Balkan exchange of minorities and its impact upon Greece. Paris, 1962. Una tesis doctoral de Mark Mazower en Oxford, 1987, estudia las consecuencias en Grecia de la gran crisis de los años treinta: Towards autarchy. The recovery from crisis in Greece, 1929-1936, Mazower, Mark. Al menos, disponemos de un resumen en italiano: «L'economia greca durante la "grande depressione" dei primi anni'30" (en Rivista di Storia Economica, 2, n. 3 , pp. 371-392). Gail E. Maniken, "The Greek Hyperinflation and Stabilization of 1943-1946", en The Journal of Economic History, 1986, XLVI, 3, que también provocaria polémica ese mismo año. Th. P. Lianos, «Political Stability and Economic Development: the Case of Greece, 1948-1966». En Journal of European Economic History, XV, 3, pp. 617-619. Roma, 1986. Para época más reciente, Xenophon Zolotas, Monetary equilibrium and economic development. With special reference to the experience of Greece 1950-1963. Princeton University Press, 1965.

Sobre el siglo $\mathrm{XX}$, un reciente estudio de sintesis de A. F. Freris, The Greek economy. In the Twentieth Century, Londres, 1986, es considerado hoy como el mejor estado de la cuestión, al que contribuyen igualmente estudios como los de E. A. Le développement industriel de la Grèce. Lausanne, 1970. Centre de Recherches Européennes; A. J. Kondonasis, A. G. Malliaris y N. S. Robinson (1983) «Political Instability and Economic Development: an Economic History Case Study of Greece, 1948-1966», publicado en Journal of European Economic History, 1983, XII, 2, 351-362. Roma. Este artículo supuso una cierta polémica en dicha publicación en los años siguientes (ver la respuesta de estos autores a las críticas recibidas en el tomo XVII de 1988). Y toda una serie de estudios sobre el desarrollo económico, su consecución y medida, y sus consecuencias: A. A. Pepelasis, "The Legal System and Economic Development of Greece», en The Journal of Economic History, 1959, XIX, 2, 173-198. Nicos Vernardakis, Econometric models for the developing economies: a case study of Greece. Londres, 1978. M. Negreponti Delivanis, Influence du développement économique sur la répartition du revenu national. París. SEDES, 1960. Adamantios Pepelasis, "Greece" en el libro que encabeza, Economic Development. Analysis and case Studies, Tokio, 1961. Hosard S. Ellis (dr.), Industrial capital in greek development. Atenas. Center of Economic Research, 1964. 


\section{El estudio regional y las relaciones exteriores}

No abundan las monografias sobre regiones, pero puede verse la interesante de M. Negreponti Delivanis, referida a la conflictiva zona norte, Le développement de la Grèce du nord depuis 1912. Salónica, 1962.

Sobre el papel del Estado, Andreas I. Psomas, The Nation, the State and the International System. The Case of modern Greece. Atenas, 1978.

En la perspectiva de la situación de Grecia en el contexto internacional ha trabajado Kostis Papadantonakis en su tesis doctoral en Cornell, 1981, Greece: The Structure of Dependence, y el trabajo "The state as instrument of induction to the periphery: the case of Greece», en R. Rubinson (ed.): Dynamics of World Development, en el núm. 4 de los Political Economy of the World-System Annuals, que dirige I. Wallerstein, pp. 47-66. Beverly Hills, 1981.

Citemos al menos un estudio comparativo con una zona próxima y de ciertas similitudes: Nicholas V. Gianaris, Greece and Yugoslavia an economic comparison. New York, 1984.

\section{B) DE LA TURQUIA OTOMANA \\ A LA REPUBLICA TURCA KEMALISTA}

\section{Visiones generales}

Mencionamos apenas algunas obras de sintesis y divulgación, siempre útiles sin embargo en estos casos de paises alejados de nuestro entorno cultural, tales como la de Robert Mantran (1952) Histoire de la Turquie, Paris; M. Philips Price (1961), A History of Turkey. From Empire to Republic, Londres; Bulent Nuri Esen (1969), La Turquie (Col. «Comment ils sont gouvernés"), París; o los de Roderic H. Davison (1988, 2.2 ed.) Turkey: a short bistory, Huntingdon, y Jean-Paul Roux (1984) Histoire des turcs. Deux mille ans du Pacifique à la Mediterranée. París.

En cuanto a estudios de mayor ambición y profundidad, afortunadamente en el último cuarto de siglo - sin duda por el protagonismo político y económico de la zona- se han prodigado muchos y en general muy buenos estudios sobre Oriente Medio que, con mayor o menor profundidad, se ocupan de Turquia. Así, uno de los primeros de esta ola, el de Sydney Nettleton Fisher (1968) The Middle East. A History, The Ohio State University, New York (la 1.2 ed. en 1959). De parecida entidad es el de William Yale 
(1968) The Near East. A Modern History. New York, Univ. of Michigan Press. (2. ${ }^{2}$ ed.).

Menor importancia, hasta el momento, han tenido los estudios sobre el área balcánica estricta, que el imperio otomano ocupó en buena parte y en la que Turquia conserva aún el importante enclave de Estambul. Una obra sólida, la de Barbara Jelavich (1983) History of the Balkans. New York. (Cambridge U. Press, $2 .^{2}$ reimpr.)

Un cuarto y principal grupo es de aquellas obras que se han ocupado del fenómeno turco a partir de Mustafá Kemal Ataturk. De la bastante amplia serie - muy desigual, la mayoría ubicados en la hagiografia propia o extranjera-, destacamos los trabajos del célebre pionero Bernard Lewis (1968) The emergence of Modern Turkey, Londres 2.2 ed. Oxford U. Press; de Kemal H. Karpat (1970), "Modern Turkey» (en el vol. I B de The Cambridge History of Islam, pp. 527-565, Cambridge University Press) y (1974) The Ottoman State and its place in World History. Leiden; de Kamuran Bekir Harputlu (1974), La Turquie dans l'impasse. Une analyse marxiste de l'Empire Ottoman ànos jours. París; de Weiker, Walter F. (1981), The Modernization of Turkey. From Atatürk to the Present Day, New York.

\section{Los estudios económicos}

La visión económica es hoy una de las principales perspectivas, máxime cuando se estudian países o zonas en profunda transformación. De ello se ha beneficiado, en lineas generales, ésta a que nos referimos. Tanto los estudios de conjunto, como los específicos sobre Turquía, abundan y son, en general, rigurosos $\mathrm{e}$ interesantes.

Entre los primeros, destaquemos un celebrado estudio comparado de Charles Issawi (1981), «Egypt, Iran and Turkey, 1800-1970: Patterns of Growth and Development", Londres, en la ya citada obra de P. Bairoch y $M$. Lévy-Leboyer, pp. 65-77, y la excelente obra del mismo autor (1982) $A n$ Economic History of the Middle East and North Africa, Londres.

Entre los segundos citemos a William M. Hale (1981), The Political and Economic Development of Modern Turkey, Londres, y, sobre todo, tres excelentes trabajos de Çaglar Keyder: (1981) The definition of a peripberial economy: Turkey 1923-1929, Cambridge U. Press; (1983) «Small Peasants Ownership in Turkey: Historical formation and present structure", en Review, VII, 1, pP. 53 107, y (1987) State \& Class in Turkey. A study in capitalist development, Londres.

Una visión desde la perspectiva de los movimientos sociales es la de 
Gülten Kazgan (1973) «Peasant movements in Turkish society since the end of the XVIIIth. century up to our times» (en Cabiers Internationaux d'Histoire Economique et Sociale. n.o 7, pp. 328 ss., Ginebra).

\section{Las grandes etapas}

\section{a) El Imperio otomano}

En los últimos quince años han proliferado los estudios sobre ese gran imperio - junto con el ruso, los últimos del Antiguo Régimen, que llegan hasta comienzos del siglo $\mathrm{XX}$ - A los primeros, y muy celebrados de Stanford J. y Ezel Kuval Shaw (1977) History of the Ottoman Empire and Modern Turkey, Cambridge U. Press. 2 vols., y a la reflexión del Journal of the F. Braudel Center (1978) «Impact of the Annales School on Ottoman Studies and New Findings». t. I, pp. 69-96, Binghampton, seguirá una serie de análisis, bien sectoriales, como el de Carter V. Findley (1980) Boreaucratic reform in the Ottoman Empire. The Sublime Porte, 1789-1922, Princeton University Press; el muy celebrado de Charles Issawi (1980) The Economic History of Turkey, 1800-1914, University of Chicago Press; el artículo de Bernard Lewis (1980) "The Ottoman Empire and its Aftermath», en Journal of Contemporary History, XV, 1, pp. 27-36 o el importante coloquio coordinado por J. L. Bacqué-Grammont y P. Dumont (eds.) (CNRS, Estrasburgo, 1980) Economie et sociétédans l'Empire Ottoman (ss. XVIII-XX). Paris, 1983, con ponencias como las de Sadun Aren (1983) «Le problème de l'industrialisation dans l'Empire Ottoman au XIXe. siècle» (pp. 449-458); Osman Okyar, «A New Look at the recent Political, Social and Economic Historiography of the Tanzimat» (pp. 33-45). Este mismo autor publicará en 1987 «A new look at the Problem of Economic Growth in the Ottoman Empire (1800-1914)». En Journal of European Economic History, XVI, 1, PP. 7-49, Roma.

Una orientación creciente a contemplar las relaciones internacionales dará obras como las de Marian Kent (ed.) (1984) The Great Powers and the End of the Ottoman Empire, Londres, Allen \& Unwin; Huri Islamoglu-Inan, Huri. (1987), The Ottoman Empire and the World-Economy, Cambridge University Press; Roger Owen (1987), The Middle East in the World Economy, 1800-1914, Londres, Methuen (anterior ed. de Cambridge, 1981); Sevket Pamuk (1987), The Ottoman Empire and European Capitalism, 1820-1913, Cambridge U. Press. Más abajo veremos otros trabajos sobre las relaciones internacionales de la República Turca. 
Un excelente grupo de trabajos, coordinados por el ya citado Çaglar Keyder, aparecerán en 1988 en un número monográfico sobre "The Ottoman Empire, XIX century transformationsm. Suny-Binghamton, N. Y., en n. ${ }^{\circ}$, vol. XI, primavera de Review of Fernand Braudel Center. [Ver tb. el vol. VIII, 3, de 1985.]

\section{b) Los jóvenes turcos y la transición bacia el kemalismo}

La época cuenta con una cuidada colección de fuentes, proporcionadas por Justin McCarthy (1982) The Arab World, Turkey and the Balkans (18781914). A Handbook of Historical Statistics. Boston.

Un testigo del momento, que publica un libro muy sugestivo, es Eliot Grinnell (ed.) (1924), Modern Turkey. A politico-economic interpretation, 19081923. New York.

Un breve pero eficaz artículo de Feroz Ahmad (1968), "The Young Turk Revolution", en Journal of Contemporary History, vol. 3, n.o 3, pp. 19-36. (n.o monográfico sobre The Middle East.) y la coetánea tesis doctoral de Victor Reuben Swenson (1968)The Young Turk Revolution. A Study of the first phase of the second turkish constitutional regime... (Johns Hopkins University) abordan esos importantes años del primer cuarto del siglo XX.

\section{c) La economia en la Turquía de M. Kemal Ataturk}

La figura de M. Kemal Ataturk ha despertado una veneración que desborda lo biográfico y aun lo estrictamente político para alcanzar aspectos psicosociales y culturales. Posiblemente no haya, ni siquera en la URSS con Marx, Lenin o Stalin, en China con Mao, etc., un tratamiento semejante de su figura, a todos lo niveles. En 1963, al cumplirse un cuarto de siglo de su desaparición, se publicaron numerosos textos, entre los que destacamos el editado por la UNESCO: Atatürk (1881-1938). Hommage de la Commisión Nationale turque por PUNESCO àloccasion du 25eme anniversaire de sa mort. Ankara. (También ese año la UNESCO editó en varios idiomas occidentales Atatürk. Ankara, traducción del 10.0 fascículo de l'Encyclopedie del'Islam, 1946.)

El segundo gran momento es 1981, al cumplirse el centenario de su nacimiento, época en la que aparecen textos como el de Feroz Ahmad (1981) "The political economy of Kemalism», Londres, en A. Kazancigil y E. 
Özbudun (eds.): Atatürk. Founder of a Modern State, (pp.145-163); A. Bodurgil (1981) Kemal Atatürk. A Centennial Bibliograpby (1881-1981), Washington; del mismo autor (1978), Turkey, politics and government: a bibliograpby, Washigton, Library of Congress. $Y$ en esa línea pueden verse el artículo de Mustafá A. Aysan (1982) "Atatürk's Economic Views», en T. Feyzioglu (ed.): Ataturkás way..., pp. 77-116, Estambul.

No hay muchos estudios sectoriales, pero podemos contar para el primario con la obra de Oddvar Aresvik (1975) The Agricultural Development of Turkey, Nueva York, Praeger. Sobre la población, F. C. Shorter y B. Gûvenç, (eds.) (1969) Turkish demograpby. Proceedings of a Conference (Actas del Encuentro de Izmir, febrero de 1968), Ankara, Hacettepe University. La mayoria de los estudios sobre historia económica, como es obvio, se orientarán hacia el proceso de industrialización.

Varios autores se han preguntado por el modelo de desarrollo; seleccionamos a Alec P. Alexander (1961), "Turkey", Tokio, en A. Pepelasis y otros: Economic Development. Analysis and Case Studies, pp. 468-499, Harper, Tokio; Lee J. Seidler (1967), The Function of Accounting in economic development. Turkey as a case study, Nueva York; Z. Y. Hershlag (1968), Turkey, The cballenge of growth. Leiden; Osman Okyar (1979), "Development Background of the Turkish Economy, 1923-1973" (en International Journal of Middle East Studies, pp. 325-344, Cambridge University Press); Bertil Wálstedt (1980), State Manufacturing Enterprise in a Mixed Economy. The Turkish Case, Baltimore, Johns Hopkins University; Gladys Nott (1981), «Indebtedness in Turkey: a political economic perspectiven, en A. Gunder Frank (intr.): International Monetary fund policies in the Third World. (Occasional paper, n. ${ }^{\circ} 8$, febrero.) East Anglia University; Berch Berberoglu, Berch (1982), Turkey in crisis: from state capitalism to neo-colonialism, London and Westport; Sevket Pamuk, Sevket (1982), "World Economic crises and the periphery: The case of Turkey", en E. Friedman (ed.): Accent and Decline in the World-System, pp. 147-161, n. 5. Political Economy... Annuals (ed. I. Wallerstein), Beverly Hills; Robert Bianchi, Robert (1984) Interest Groups and Political Development in Turkey, Princeton Univ. Press; el número 11, monográfico de la revista Kbamsin (1984) «Modern Turkey: development \& crisis (Londres) (con importantes artículos de $T$. Taylan, A. Ende, P. Yorgun, M. Saláh, R. Ayres.); la obra colectiva encabezada por J. M. Landau (ed.): Atatürk and the modernisation of Turkey, Boulder, Colorado, 1984; Huseyin Ramazanoglu (ed.) (1986) Turkey in the world capitalist system. A Study of industrialisation, power and class, Aldershot.

Muy sugestivo es el punto de vista comparado que ofrecen Ward, R. E., y Rustow, D. A. (eds.) (1964), Political Modernization in Japan and Turkey, 
Princeton U. Press; Trimberger, Ellen Kay (1978), Revolution from above, Military Bureaucrats and Development in Japan, Turkey, Egypt and Peru. New Brunswick (Rutgers University, N. Jersey.); Geneve Takeshi Hayashi (1981), "The modernisation of Japan and Turkey: some comparisons", Londres, en A. Kazancigil y E. Ozbudun: Atatürk. Founder of a Modern State, pp. 221-234.

Para la consideración del papel del estado, Martin Heper (1985), The State tradition in Turkey, Hull University.

Sobre el papel del empresariado, Alec P. Alexander (1960), «Industrial entrepreneurship in Turkey: Origins.

A la hora de destacar algunas de las principales mejoras sociales, hay dos libros importantes sobre el cambio en el papel de la mujer en la sociedad turca: los de Nermin Abadan-Unat (ed.) (1981), Women in Turkish Society, Leiden, y Janet Browning (1985), Atatürk's legacy to the Women of Turkey, Durham University. Occasional papers, n. ${ }^{\circ} 27$. Sobre los cambios educativos es útil leer a M. Andreas Kazamias (1966), Education and the quest for modernity in Turkey, Londres, y a Ilhan Basgöz y Howard E. Wilson(1968), Educational problems in Turkey, 1920-1940, Bloomington. Indiana University.

Sobre las relaciones - políticas y, sobre todo económicas- con las grandes potencias han escrito Roger R. Trask (1964), "The United States and Turkish Nationalism: Investments and Technical Aid during the Atatürk Era», en Busines History Revue, vol. 38, n. 1, pp. 58-66, Boston. Y también, del mismo autor (1971), The U.S. Response to Turkish Nationalism and reform, 1914-1939. The University of Minnesota Press; Antoine Fleury (1977), La pénétration allemand au Moyen-Orient, 1919-1939. Le cas de la Turquie, de II Iran el de I'Afgbanistan; Stephen F. Evans (1982), The Slow rapprochement: Britain and Turkey in the age of Kemal Atatürk, 1919-38, The Eoten Press. Univ. of Hull; Ismail Soysal (1986), "Les relations politiques turco-français (1921-1985)». Estambul, en la citada obra dirigida por H. Batu y J. L. Bacqué Grammont: L'Empire Otoman..., pp. 587-698; Uriel Dann (ed.) (1988), The Great Powers in the Middle East, 1919-1939, Tel Aviv University, Nueva York; Turgut Taylan (s.a.), "Capital and the state in contemporary Turkey", Londres, en n. 11 de Khamsin, pp. 5-46. 